\title{
PARENTS’ IMPACT ON STUDENTS’ READING ACHIEVEMENT
}

\author{
Andrejs Geske \\ University of Latvia, Latvia \\ Antra Ozola \\ University of Latvia, Latvia
}

\begin{abstract}
Scientific studies have proved that a family has a high impact on the students' academic achievement, including their reading literacy. This paper focuses on the parents' undertaken activities for promoting the development of child's reading literacy at the preschool age (reading together, singing, discussing the read text with a child, playing together, etc.) to explore the impact of these activities upon the reading literacy achievement of students in Grade 4. The research problem addresses the following questions: whether and to what extent the parents' undertaken activities for promoting the development of child's reading literacy at the preschool age have an impact on students' reading skills at the end of their fourth school year. The analysis is based on the research results from students' tests, students' and parents' questionnaires of the Progress in International Reading Literacy Study (PIRLS) 2016, organised by the International Association for Evaluation of Educational Achievement (IEA). The impact of parents' activities carried out together with their preschool aged children was studied performing a linear regression analysis along with a frequency and correlation analysis.

A higher reading achievement was demonstrated by those fourth graders whose parents were actively involved in reading promotion activities. Although one determining activity could not be stated, reading together and storytelling were found to be significant. Parents' education correlated positively with the frequency of their undertaken reading promotion activities; thus, the parents' education was approved to have a multifaceted impact on a child's reading achievement.
\end{abstract}

Keywords: children's reading literacy, parents, PIRLS.

\section{Introduction}

Students' reading literacy achievement is related to the total academic achievement and success in the education process. Families and their undertaken activities, schools and libraries, when closely collaborating, have a fundamental role for the improvement of students' reading literacy. The paper explores what parents' undertaken activities, done together with a child at the preschool age, have an impact on the development and further improvement of reading literacy in the child's fourth year of schooling. 
The study analyses students' tests, students' and parents' questionnaires of the Progress in International Reading Literacy Study (PIRLS) 2016, organised by the International Association for Evaluation of Educational Achievement (IEA). The IEA's PIRLS is a large scale international comparative study of reading literacy achievement of fourth grade students. Since 2000 PIRLS is conducted every five years.

The aim of the research is to examine whether and to what extent the parents' undertaken activities for promoting the development of child's reading literacy at the preschool age have an impact on students' reading skills at the end of their fourth school year. A linear regression analysis has been performed along with a frequency and correlation analysis. The research unit is a country.

\section{Literature Review}

A family is considered as the most determining factor affecting a child's reading literacy and education in general (European Union, 2012). Besides, parents' education is one of the key factors contributing to the students' reading literacy and academic achievement. Myrberg and Rosen (2009) state that children have lower results for reading if their parents have low level of education. Yet, according to Araujo and Costa (2011), reading literacy results are significantly increased when parents read aloud to their children at the preschool age, despite the level of parents' education. However, there is an obvious correlation between the parents' education and their desire to read aloud: the higher level of education parents have, more often they would read to their children.

Family socioeconomic status is mainly determined by the level of parents' education. Students from low-socioeconomic status families are not capable to achieve standard requirements for reading already in primary school (Scottish Government, 2010). It can be related to the lack of parents' knowledge and skills to work with their children and develop cognitive skills; due to that there are many children who start attending school with rather poor skills (European Union, 2012).

Insufficient financial resources affect the family expense priorities, too; new books will not be goods of prime necessity. Several countries solve this situation by developing support programmes. For example, in Portugal a specific digital platform is designed where children's books are available electronically. Araujo and Costa (2011) indicate that an increased emphasis worldwide is placed upon the reading acquisition and practice as early as possible. To comprehend a text is a complex task that requires different cognitive skills and processes (Cain, Bryant, \& Oakhill, 2004). Therefore, this task should be performed since an early childhood in order to address acquisitive processes and build the foundation for further acquisition activities. 
Gove and Cvelich (2011) claim that a lack of books at school and at home as a critical component affects the acquisition of reading skills. Other key components are reading habits of family members as, for example, those parents and grandparents who read serve as positive role models; meanwhile, children have opportunities to discuss what they have read with individuals whose opinion they respect or to accept constructive suggestions (Latvijas Kultūras akadēmija, 2018). With reference to Human Resource Development Centre (2017), children highly value such activities where parents introduce them to books, showing pictures, reading aloud, counting etc. because they associate these activities with a mother's love.

The parents' role for enhancing reading literacy is fundamental; this impact determines whether a child will become a reader for life or not. Wildova and Kropackova (2015) point out that initially parents have to think about their intonation, speed etc. when they read aloud because children will perceive it as a model and will try to imitate; it refers to teachers, too. When parents read aloud to children, they stimulate their interest in a written word, which is essential in the early stages of reading literacy development. Unfortunately, the studies carried out in Latvia show that $46.4 \%$ of fathers and $29.8 \%$ of mothers read aloud to their children insufficiently often; $19,6 \%$ of fathers and $7.9 \%$ of mothers do not read to their children at all; $26.8 \%$ of fathers and $21.9 \%$ of mothers read aloud just several times a month (Vanags, 2019). Vanags (2019) observes a significant correlation: indicators for low level of reading aloud are closely related to the parents' own childhood experience as $47.5 \%$ of parents admitted that their own parents insufficiently or rarely read aloud to them in childhood.

The parents' role model is crucial for a child to be interested in reading and exploring why there are newspapers, magazines and books in the family on a daily basis. Human Resource Development Centre (2017) declares that children will practise reading as a daily ritual and feel motivated to read naturally when they will observe their parents as regular readers.

\section{Methodology}

The paper analyses the IEA's PIRLS 2016 data from students' tests, students' and parents' questionnaires. The impact of parents' undertaken activities at the preschool age of their children was studied in each cycle of the study, performing a linear regression, frequency and correlation analysis.

The responses of fourth grade students' parents were analysed to the question "Before your child began primary/elementary school, how often did you or someone else in your home do the following activities with him or her?", meanwhile, searching for the correlation between the undertaken activities and students' reading literacy achievement. The parents could indicate how often 
(often, sometimes, never or almost never) they did each of the following activities together with their preschool aged children:

a) Read books;

b) Tell stories;

c) Sing songs;

d) Play with alphabet toys (e.g. blocks with letters of the alphabet);

e) Talk about things you had done;

f) Talk about what you had read;

g) Play word games;

h) Write letters or words;

i) Read aloud signs and labels;

j) Say counting rhymes or sing counting songs;

k) Play with number toys (e.g. blocks with numbers);

l) Count different things;

m) Play games involving shapes (e.g. shape sorting toys, puzzles);

n) Play with building blocks or construction toys;

o) Play board or card games;

p) Write numbers.

On the basis of the collected responses, a parental activity index was created, calculating an average value for each response.

The dependent variable of the linear regression equation was the student reading literacy achievement in the PIRLS test. The parental activities undertaken at the child's preschool age were the independent variable (see Table 2). Besides, additional variables were included in the equations that characterised students and their family; they were parents' education, student's gender, the use of the test language at home, preschool learning experience (see Table 3). A country was chosen as a research unit.

In the PIRLS questionnaire the parents were asked to indicate their highest level of the formal education. They could choose one of the following responses: did not attend school, an incomplete basic school, a completed basic school, a completed secondary school, a completed education after the secondary school (vocational education, which is not a higher education), a completed first-level professional higher education (college), a bachelor degree or a completed secondlevel professional higher education, a master's degree, a doctor's degree. The study focused on those parents who had a higher level of education.

To include the chosen category as a variable in the regression equation, the total number of years spent at school and higher education institutions was calculated. The methodology and relevant data of the Organisation for Economic Co-operation and Development (OECD) Programme for International Student Assessment (PISA) were used (Organisation for Economic Co-operation and Development, 2017). 


\section{Research Results}

Despite the statistically significant correlation between the frequency of parents' undertaken activities for the development of children's reading literacy and the level of parents' education, these variables were not substitutable. Parents who had a higher level of education typically carried out such reading activities for increasing their children's literacy that were not included in the questionnaire and could not be displayed separately, for instance, parents demonstrated a wide range of vocabulary when speaking, spoke about different topics, motivated children to read skilfully, as well as did many other possible activities.

The PIRLS 2016 data showed that the lowest average level of education for fourth grade parents was in Morocco (a bit less than 8 years) and in Iran (11.1 years). Parents from Canada, Norway, Denmark, Australia, Dubai and Moscow had the longest period of formal education, i.e. more than 15 years. The remarkable length of formal education (15.7 years) for parents in Moscow should be highlighted as it correlated with the very high reading literacy achievement of students in Moscow, which was the highest in the PIRLS 2016. In Latvia, the average length of education was 14.6 years, which was a shorter period in comparison with the neighbouring countries Finland, Sweden, Lithuania and Russia.

The education of parents was a statistically considerable factor in the multifactor regression equations, which affected the reading literacy achievement in all the participant countries, except in Hong Kong. The correlation between the level of parents' education and the students' reading achievement in Latvia and its nearest countries is shown in Table 1. When comparing the length of parents' education in 2016 and 2006, it can be concluded that for those countries which participated in both cycles of the PIRLS the length of education had increased for an average of 0.8 years, i.e. from 13.0 to 13.8 years. The only country where the length of education for parents had slightly decreased (for 0.2 years) was Georgia; however, it had increased in other participant countries. The most significant increase was observed in Iran (from 9.2 to 11.1 years), Germany (from 11.8 to 13.7 years) and Singapore (from 12.8 to 14.6 years). The increase in Latvia was below the average, i.e. for nearly half a year. 
Table 1 The Correlation Between the Level of Parents' Education and the Students' Reading Achievement (RA) in Latvia and Its Nearest Countries

\begin{tabular}{|l|c|c|c|c|c|c|c|c|}
\hline \multirow{2}{*}{$\begin{array}{l}\text { Education of } \\
\text { Parents }\end{array}$} & \multicolumn{2}{|c|}{ Lithuania } & \multicolumn{2}{c|}{ Latvia } & \multicolumn{2}{c|}{ Finland } & \multicolumn{2}{c|}{ Russia } \\
\cline { 2 - 9 } & $\begin{array}{c}\text { Children's } \\
\text { RA }\end{array}$ & $\begin{array}{c}\text { Parents } \\
\%\end{array}$ & $\begin{array}{c}\text { Children's } \\
\text { RA }\end{array}$ & $\begin{array}{c}\text { Parents } \\
\%\end{array}$ & $\begin{array}{c}\text { Children's } \\
\text { RA }\end{array}$ & $\begin{array}{c}\text { Parents } \\
\%\end{array}$ & $\begin{array}{c}\text { Children's } \\
\text { RA }\end{array}$ & $\begin{array}{c}\text { Parents } \\
\%\end{array}$ \\
\hline $\begin{array}{l}\text { Bachelor's or } \\
\text { higher degree }\end{array}$ & 576 & $45.4 \%$ & 578 & $47.3 \%$ & 585 & $53.9 \%$ & 601 & $50.6 \%$ \\
\hline $\begin{array}{l}\text { Higher than } \\
\text { secondary } \\
\text { school, but no } \\
\text { bachelor's } \\
\text { degree }\end{array}$ & 533 & $39.8 \%$ & 549 & $33.4 \%$ & 559 & $20.1 \%$ & 566 & $37.2 \%$ \\
\hline $\begin{array}{l}\text { Secondary } \\
\text { school }\end{array}$ & 512 & $8.5 \%$ & 535 & $12.3 \%$ & 547 & $23.6 \%$ & 552 & $6.8 \%$ \\
\hline Basic school & 501 & $3.8 \%$ & 521 & $5.8 \%$ & 519 & $1.6 \%$ & 528 & $4.5 \%$ \\
\hline $\begin{array}{l}\text { Primary school } \\
\text { or lower }\end{array}$ & 482 & $0.6 \%$ & 509 & $0.7 \%$ & 441 & $0.3 \%$ & 505 & $0.3 \%$ \\
\hline No response & 551 & $1.9 \%$ & 549 & $0.5 \%$ & 509 & $0.4 \%$ & 585 & $0.7 \%$ \\
\hline
\end{tabular}

Analysing the data, the following key factors affecting the further development and achievement of reading literacy were determined: parents' education, the frequency of the test language used at home, and the length of time a child has attended a preschool education institution. As the stated factors were related to the child's preschool period, they were included in the regression equations as control variables in this study. Due to differences of the reading literacy achievement between girls and boys, the gender of students was included as a control variable in the linear regression models, too.

To make a valid comparison between the impact of parents' undertaken distinct activities at the preschool age on the child's reading literacy achievement in Grade 4, nine coefficients of regression equations were derived representing the parents' response "Often" to the relevant activity, i.e. the relationship between a categorical variable and a response "Never or almost never" (see Table 2). For example, parents often read books aloud together with their child or often told stories. The most positive impact on the students' reading achievement was achieved when parents frequently read books together with a child. Only in five participant countries the relevant regression coefficients for this activity were statistically insignificant, including the results of Latvia. Storytelling was the next most effective parental activity. Definitely, this activity involves the traditional bedtime stories in Latvia. The linear regression model, however, did not show the statistical significance of this activity for the students' reading achievement in Latvia. Cross-examining all the results of the PIRLS 2016 participant countries, it was identified that a minimal impact occurred from playing with alphabet toys, 
singing songs and talking about things one had done. Besides, it was hard to explain the gained finding that, in the case of Latvia, the word and letter writing activity done together with parents at the preschool age had a negative statistically significant impact on the students' reading achievement. Possibly, these activities were carried out far too early or late. A similar situation was identified only in Georgia.

The data analysis showed that there is no such one and the most effective activity that enhances the reading literacy of preschool aged children. The high correlation between undertaken activities should be observed, for example, those parents who frequently read together with their child, often told stories and fairy tales, too.

Table 2 Regression Coefficients of Nine Regression Equations Representing the Parents' Response "Often" for the Undertaken Activities to Enhance the Development of Reading Literacy Together with a Child at the Preschool Age

\begin{tabular}{|c|c|c|c|c|c|c|c|c|c|}
\hline $\begin{array}{l}\text { PIRLS } 2016 \\
\text { participants }\end{array}$ & $\begin{array}{l}\text { Read } \\
\text { books }\end{array}$ & $\begin{array}{l}\text { Told } \\
\text { stories }\end{array}$ & \begin{tabular}{|l|} 
Sang \\
songs
\end{tabular} & $\begin{array}{l}\text { Played } \\
\text { with } \\
\text { alphabet } \\
\text { toys }\end{array}$ & \begin{tabular}{|l} 
Talked \\
about \\
things \\
what had \\
been done
\end{tabular} & $\begin{array}{l}\text { Talked } \\
\text { about } \\
\text { what had } \\
\text { been read }\end{array}$ & \begin{tabular}{|l} 
Played \\
word \\
games
\end{tabular} & $\begin{array}{l}\text { Wrote } \\
\text { letters } \\
\text { or } \\
\text { words }\end{array}$ & $\begin{array}{l}\text { Read } \\
\text { aloud } \\
\text { signs } \\
\text { and } \\
\text { labels } \\
\end{array}$ \\
\hline $\begin{array}{l}\text { Buenos Aires, } \\
\text { Argentina }\end{array}$ & $37 *$ & $47^{*}$ & $19 *$ & $27^{*}$ & $44^{*}$ & $18^{*}$ & $22 *$ & $13^{*}$ & $24 *$ \\
\hline Australia & 28 & $12^{*}$ & -2 & 6 & $22 *$ & 12 & 9 & $21^{*}$ & $26 *$ \\
\hline Austria & $24 *$ & $14^{*}$ & $12^{*}$ & -2 & 9* & 6 & $19 *$ & -7 & 6 \\
\hline Azerbaijan & $31 *$ & $34 *$ & 1 & 5 & -1 & $18 *$ & $13^{*}$ & $25 *$ & $14^{*}$ \\
\hline Bahrain & $52 *$ & 37* & $15^{*}$ & 7 & $26^{*}$ & $15^{*}$ & $23^{*}$ & $23 *$ & $14 *$ \\
\hline $\begin{array}{l}\text { Belgium } \\
\text { (Flemish) }\end{array}$ & $26^{*}$ & $28 *$ & $11^{*}$ & 1 & $18^{*}$ & $14^{*}$ & $13^{*}$ & 1 & $11^{*}$ \\
\hline $\begin{array}{l}\text { Belgium } \\
\text { (French) }\end{array}$ & $35^{*}$ & $20^{*}$ & $10^{*}$ & 6 & $24^{*}$ & $11^{*}$ & $12^{*}$ & 2 & 0 \\
\hline Bulgaria & $31 *$ & $29 *$ & $14^{*}$ & $20 *$ & 33* & $22 *$ & $15^{*}$ & $29 *$ & $16^{*}$ \\
\hline Canada & $34 *$ & $15 *$ & $9 *$ & $21 *$ & 13 & $17 *$ & $18^{*}$ & 19* & $17 *$ \\
\hline $\begin{array}{l}\text { Ontario, } \\
\text { Canada }\end{array}$ & $43^{*}$ & 10 & $9 *$ & 14 & 9 & $21^{*}$ & $25^{*}$ & $24 *$ & 9 \\
\hline $\begin{array}{l}\text { Quebec, } \\
\text { Canada }\end{array}$ & $23 *$ & $24 *$ & 5 & 8 & 7 & $11^{*}$ & $13^{*}$ & $17 *$ & 10 \\
\hline Chile & $29 *$ & $29 *$ & -2 & $15 *$ & $27 *$ & 8 & $18^{*}$ & $18 *$ & $17 *$ \\
\hline Taiwan & $40 *$ & $32 *$ & 1 & $18 *$ & 3 & $6 *$ & $23^{*}$ & $16^{*}$ & $17^{*}$ \\
\hline Czech Republic & $57 *$ & $21 *$ & 5 & -2 & 21 & $16^{*}$ & $13^{*}$ & 3 & 8 \\
\hline Denmark & $34 *$ & $5 *$ & $11^{*}$ & $9 *$ & 17 & $18^{*}$ & $16^{*}$ & $21 *$ & $27 *$ \\
\hline Finland & $42 *$ & $13 *$ & $20 *$ & $11 *$ & 11 & $13^{*}$ & 1 & $22 *$ & $17 *$ \\
\hline France & $39 *$ & $27 *$ & 7 & $11 *$ & 5 & $5^{*}$ & $14^{*}$ & 2 & 4 \\
\hline Georgia & -19 & -9 & 3 & -5 & -1 & 4 & -10 & $-16^{*}$ & -13 \\
\hline Germany & $33 *$ & $25 *$ & $16^{*}$ & -3 & 13 & $13 *$ & 8 & -1 & 6 \\
\hline $\begin{array}{l}\text { Hong Kong } \\
\text { SAR }\end{array}$ & $31^{*}$ & $20 *$ & -2 & 6 & -7 & -3 & 9 & 6 & $11^{*}$ \\
\hline
\end{tabular}


Geske \& Ozola, 2020. Parents' Impact on Students’ Reading Achievement

\begin{tabular}{|c|c|c|c|c|c|c|c|c|c|}
\hline Hungary & $29 *$ & $39 *$ & 3 & 8 & 42 & 0 & 11 & 4 & $13 *$ \\
\hline Iran & $42^{*}$ & $36 *$ & 5 & 4 & 23 & 11 & 11 & 10 & 14 \\
\hline Ireland & $55^{*}$ & $30 *$ & 14 & $18^{*}$ & $67 *$ & $25^{*}$ & $20^{*}$ & $37 *$ & $30 *$ \\
\hline Israel & $35^{*}$ & 29* & $17 *$ & -1 & -1 & -3 & $18^{*}$ & -3 & -1 \\
\hline Italy & $28 *$ & $19 *$ & -3 & 6 & 16 & $15^{*}$ & $10^{*}$ & 1 & 1 \\
\hline Kazakhstan & 18 & -9 & 3 & 9 & 11 & 13 & 5 & 2 & -5 \\
\hline Latvia & 13 & 3 & -4 & 0 & 15 & 1 & $11^{*}$ & $-19 *$ & 2 \\
\hline Lithuania & $32 *$ & 5 & 3 & 0 & 5 & 11 & $9 *$ & 8 & 5 \\
\hline Macau & $34 *$ & $25^{*}$ & 3 & $12^{*}$ & 4 & 7* & $16^{*}$ & $12^{*}$ & 8 \\
\hline Malta & $42 *$ & $34 *$ & $21^{*}$ & 17 & 20 & $32 *$ & $19 *$ & $22 *$ & $30 *$ \\
\hline Morocco & 9 & $21^{*}$ & -5 & 6 & $27 *$ & $16^{*}$ & $22^{*}$ & $29 *$ & $20^{*}$ \\
\hline Netherlands & $39 *$ & $12 *$ & $22 *$ & 0 & -5 & 11 & 8 & 3 & $10^{*}$ \\
\hline New Zealand & $81^{*}$ & $47^{*}$ & $26^{*}$ & $34 *$ & 16 & $35^{*}$ & $27^{*}$ & $23^{*}$ & $24 *$ \\
\hline $\begin{array}{l}\text { Northern } \\
\text { Ireland }\end{array}$ & $34 *$ & $12^{*}$ & $17^{*}$ & 9* & -8 & $20^{*}$ & $18^{*}$ & $18^{*}$ & $11^{*}$ \\
\hline Norway & $40^{*}$ & $6^{*}$ & $15^{*}$ & $17^{*}$ & -2 & $19 *$ & $23^{*}$ & $15^{*}$ & $15^{*}$ \\
\hline Norway (4) & $41^{*}$ & $49 *$ & $7 *$ & $23 *$ & $32 *$ & $30^{*}$ & $26^{*}$ & $41^{*}$ & $37 *$ \\
\hline Oman & 27 & -1 & -7 & 1 & -15 & 15 & 10 & 6 & 2 \\
\hline Poland & $45^{*}$ & $34^{*}$ & 1 & $11^{*}$ & $22 *$ & $14^{*}$ & $16^{*}$ & 3 & $11 *$ \\
\hline Portugal & $56 *$ & $56 *$ & $13^{*}$ & $21 *$ & $15^{*}$ & $16^{*}$ & $13^{*}$ & $19 *$ & $28 *$ \\
\hline Qatar & $23^{*}$ & 7 & 7 & 2 & 9 & $10^{*}$ & $17^{*}$ & 6 & $21^{*}$ \\
\hline Russia & $35 *$ & $28^{*}$ & 9* & 1 & $28 *$ & $20^{*}$ & $15^{*}$ & 1 & -1 \\
\hline $\begin{array}{l}\text { Moscow, } \\
\text { Russia }\end{array}$ & $20^{*}$ & $20 *$ & 6 & 4 & 9 & $13^{*}$ & $13^{*}$ & $18^{*}$ & 6 \\
\hline Saudi Arabia & $43^{*}$ & $30 *$ & 1 & 3 & 9* & $11^{*}$ & $17^{*}$ & $12^{*}$ & $10^{*}$ \\
\hline Singapore & $87 *$ & $39 *$ & 2 & $28 *$ & 73* & $42 *$ & $38^{*}$ & 6 & $18^{*}$ \\
\hline $\begin{array}{l}\text { Slovak } \\
\text { Republic } \\
\end{array}$ & $52 *$ & 5 & $17^{*}$ & $10 *$ & $52 *$ & $14^{*}$ & $19 *$ & 7 & $18^{*}$ \\
\hline Slovenia & $23^{*}$ & 19 & -6 & $22 *$ & 10 & -18 & 5 & 13 & 20 \\
\hline South Africa & $32 *$ & $22 *$ & 7* & $16^{*}$ & 33* & $18^{*}$ & $15^{*}$ & $12^{*}$ & 13 \\
\hline Spain & $27^{*}$ & $28^{*}$ & 4 & $8 *$ & $37^{*}$ & $19^{*}$ & $16^{*}$ & 9 & 11 \\
\hline $\begin{array}{l}\text { Andalusia, } \\
\text { Spain }\end{array}$ & $29^{*}$ & $25 *$ & 7 & 7 & 16 & 8 & 5 & 6 & 7 \\
\hline Madrid, Spain & $40 *$ & $8^{*}$ & 8 & 5 & 29 & $10^{*}$ & 6 & $19 *$ & $13^{*}$ \\
\hline Sweden & $66^{*}$ & $51^{*}$ & $28^{*}$ & $37 *$ & $40^{*}$ & $31^{*}$ & $26^{*}$ & $25^{*}$ & $40 *$ \\
\hline $\begin{array}{l}\text { Trinidad and } \\
\text { Tobago }\end{array}$ & $99 *$ & $79 *$ & $21^{*}$ & $25 *$ & $11^{*}$ & $13^{*}$ & $23^{*}$ & $19^{*}$ & $15^{*}$ \\
\hline $\begin{array}{l}\text { United Arab } \\
\text { Emirates }\end{array}$ & $89 *$ & $72^{*}$ & $18^{*}$ & $34^{*}$ & 10 & 5 & $22^{*}$ & $20 *$ & $16 *$ \\
\hline $\begin{array}{l}\text { Abu Dhabi, } \\
\text { UAE }\end{array}$ & $92 *$ & $69 *$ & $14^{*}$ & $22 *$ & 6 & $19 *$ & $25^{*}$ & $18^{*}$ & $19 *$ \\
\hline MIN & $-19 *$ & $-9 *$ & $-7^{*}$ & $-5^{*}$ & $-15^{*}$ & $-18 *$ & $-10^{*}$ & $-19 *$ & $-13^{*}$ \\
\hline MAX & 99* & $79 *$ & $28^{*}$ & $37 *$ & $73 *$ & $42^{*}$ & $38^{*}$ & $41^{*}$ & $40 *$ \\
\hline AVERAGE & $39 *$ & $26 *$ & 8* & $11^{*}$ & $18^{*}$ & $14^{*}$ & $15^{*}$ & $12^{*}$ & $13 *$ \\
\hline
\end{tabular}

* Coefficients statistically significant for confidence interval of $95 \%$.

Within the study an index of parental activity was used; the index was calculated as the average value from all of the parents' undertaken activities. The index average value was 2.4; it was the lowest in Morocco (1.9) and the highest 
SOCIETY. INTEGRATION. EDUCATION

Proceedings of the International Scientific Conference. Volume III, May $22^{\text {th }}-23^{\text {th }}$, 2020. 656-666

in Moscow (2.6). The reliability (Cronbach's alpha) of the index ranged from 0.69 in Germany to 0.82 in New Zealand, 0.76 on average. Table 3 shows the coefficients of the linear regression model where the index of parental activity was included as an independent variable. As it can be seen, it was statistically significant in all countries, except in Georgia and South Africa. In Latvia, the value of this coefficient was comparatively low, it means that the parental activities, which were undertaken at the preschool age, made a comparatively lower impact on the students' reading literacy achievement subsequently. Also, it could be identified when examining the relatively low regression coefficients for particular activities. The coefficient values were even lower, still statistically significant in Poland, Kazakhstan and Hong Kong.

Table 3 Coefficients of the Regression Equation Including an Index of Parental Activity

\begin{tabular}{|c|c|c|c|c|c|c|}
\hline $\begin{array}{l}\text { PIRLS } 2016 \\
\text { participants }\end{array}$ & Constant & $\begin{array}{l}\text { Parents' } \\
\text { education } \\
\text { in years }\end{array}$ & \begin{tabular}{|l} 
Child's \\
gender - \\
girl
\end{tabular} & $\begin{array}{l}\text { The test } \\
\text { language } \\
\text { spoken at } \\
\text { home }\end{array}$ & \begin{tabular}{|l} 
Preschool \\
attended for \\
3 or more \\
than 3 years
\end{tabular} & $\begin{array}{l}\text { Index of } \\
\text { parental } \\
\text { activity } \\
\text { (average) }\end{array}$ \\
\hline $\begin{array}{l}\text { Buenos Aires, } \\
\text { Argentina }\end{array}$ & 261 & $7 *$ & $10^{*}$ & 13 & $22 *$ & $42 *$ \\
\hline Australia & 298 & $12 *$ & $19 *$ & 21 & -4 & $22 *$ \\
\hline Austria & 323 & $10 *$ & 4 & $35 *$ & 9* & $20 *$ \\
\hline Azerbaijan & 316 & $7 *$ & $14^{*}$ & 16 & 7 & $18^{*}$ \\
\hline Bahrain & 175 & $11 *$ & $38 *$ & 2 & -7 & $43^{*}$ \\
\hline Belgium (Flemish) & 360 & $6^{*}$ & $8^{*}$ & $20^{*}$ & $18^{*}$ & $22 *$ \\
\hline Belgium (French) & 311 & $7 *$ & $10 *$ & $19 *$ & $12 *$ & $23 *$ \\
\hline Bulgaria & 328 & $10^{*}$ & $13^{*}$ & $22^{*}$ & 1 & $28^{*}$ \\
\hline Canada & 326 & $10^{*}$ & $13^{*}$ & 3 & 7* & $29 *$ \\
\hline Ontario, Canada & 322 & $10 *$ & $15 *$ & -1 & 8 & $30 *$ \\
\hline Quebec, Canada & 372 & 7* & 9* & 10 & 5 & $21^{*}$ \\
\hline Chile & 275 & 9* & $13^{*}$ & $29 *$ & -1 & $30^{*}$ \\
\hline Taiwan & 400 & $7 *$ & $6 *$ & $16^{*}$ & $5 *$ & $23^{*}$ \\
\hline Czech Republic & 316 & $10^{*}$ & $9 *$ & $30 *$ & $11^{*}$ & $22 *$ \\
\hline Denmark & 313 & $7 *$ & $11^{*}$ & $28 *$ & $33 *$ & $31^{*}$ \\
\hline Finland & 340 & $8^{*}$ & $18^{*}$ & $43^{*}$ & -4 & $27 *$ \\
\hline France & 335 & $8 *$ & $9 *$ & $14^{*}$ & $12^{*}$ & $21^{*}$ \\
\hline Georgia & 316 & $10 *$ & $21 *$ & $35 *$ & 1 & -3 \\
\hline Germany & 304 & $10^{*}$ & $6^{*}$ & $31 *$ & $11^{*}$ & $29 *$ \\
\hline Hong Kong SAR & 542 & $1 *$ & $9 *$ & $-14 *$ & -3 & $11 *$ \\
\hline Hungary & 348 & $14^{*}$ & $11^{*}$ & -29 & $10^{*}$ & $17^{*}$ \\
\hline Iran & 245 & $8^{*}$ & $35 *$ & $52 *$ & 11 & $20 *$ \\
\hline Ireland & 333 & 7* & $10^{*}$ & $22^{*}$ & 3 & $41^{*}$ \\
\hline Israel & 241 & $12^{*}$ & $13^{*}$ & $26 *$ & $52^{*}$ & $20^{*}$ \\
\hline Italy & 379 & $7 *$ & $5 *$ & $29 *$ & $17 *$ & $17 *$ \\
\hline Kazakhstan & 431 & $3^{*}$ & $10^{*}$ & 19* & $17^{*}$ & $11^{*}$ \\
\hline Latvia & 366 & 7* & $17 *$ & $29 *$ & $13^{*}$ & $15^{*}$ \\
\hline Lithuania & 324 & $10 *$ & $19 *$ & $15^{*}$ & $14^{*}$ & $16^{*}$ \\
\hline
\end{tabular}




\begin{tabular}{|l|c|c|c|c|c|c|}
\hline Macau & 465 & $2^{*}$ & $8^{*}$ & $13^{*}$ & 3 & $19^{*}$ \\
\hline Malta & 255 & $5^{*}$ & $19^{*}$ & $64^{*}$ & 1 & $34^{*}$ \\
\hline Morocco & 249 & $7^{*}$ & $22^{*}$ & 4 & $19^{*}$ & $20^{*}$ \\
\hline Netherlands & 379 & $7^{*}$ & $6^{*}$ & 8 & $13^{*}$ & $20^{*}$ \\
\hline New Zealand & 264 & $9^{*}$ & $21^{*}$ & $45^{*}$ & 2 & $41^{*}$ \\
\hline Northern Ireland & 363 & $7^{*}$ & $19^{*}$ & 11 & $13^{*}$ & $26^{*}$ \\
\hline Norway & 305 & $8^{*}$ & $15^{*}$ & 8 & $7^{*}$ & $32^{*}$ \\
\hline Norway (4) & 173 & $9^{*}$ & $39^{*}$ & 3 & $11^{*}$ & $49^{*}$ \\
\hline Oman & 413 & $8^{*}$ & $18^{*}$ & 5 & 3 & $13^{*}$ \\
\hline Poland & 367 & $5^{*}$ & 1 & $41^{*}$ & 1 & $26^{*}$ \\
\hline Portugal & 143 & $14^{*}$ & $28^{*}$ & -3 & 1 & $42^{*}$ \\
\hline Qatar & 337 & $10^{*}$ & $14^{*}$ & $39^{*}$ & $8^{*}$ & $18^{*}$ \\
\hline Russia & 322 & $11^{*}$ & $15^{*}$ & $52^{*}$ & -2 & $23^{*}$ \\
\hline Moscow, Russia & 310 & $3^{*}$ & $63^{*}$ & 2 & $20^{*}$ & $21^{*}$ \\
\hline Saudi Arabia & 351 & $9^{*}$ & $15^{*}$ & $16^{*}$ & $28^{*}$ & $22^{*}$ \\
\hline Singapore & 220 & $11^{*}$ & $6^{*}$ & $68^{*}$ & $26^{*}$ & $32^{*}$ \\
\hline Slovak Republic & 286 & $10^{*}$ & $15^{*}$ & $20^{*}$ & $12^{*}$ & $33^{*}$ \\
\hline Slovenia & 210 & $12^{*}$ & $27^{*}$ & $33^{*}$ & $20^{*}$ & 11 \\
\hline South Africa & 389 & $4^{*}$ & $5^{*}$ & $12^{*}$ & $8^{*}$ & $30^{*}$ \\
\hline Spain & 390 & $5^{*}$ & 0 & $15^{*}$ & $8^{*}$ & $25^{*}$ \\
\hline Andalusia, Spain & 425 & $4^{*}$ & 4 & $11^{*}$ & $8^{*}$ & $21^{*}$ \\
\hline Madrid, Spain & 353 & $8^{*}$ & $13^{*}$ & $22^{*}$ & $12^{*}$ & $21^{*}$ \\
\hline Sweden & 235 & $8^{*}$ & $18^{*}$ & 11 & $-12^{*}$ & $53^{*}$ \\
\hline Trinidad and Tobago & 134 & $12^{*}$ & $23^{*}$ & 5 & $24^{*}$ & $53^{*}$ \\
\hline United Arab Emirates & 120 & $12^{*}$ & $30^{*}$ & -9 & $36^{*}$ & $49^{*}$ \\
\hline
\end{tabular}

* Coefficients statistically significant for confidence interval of $95 \%$.

\section{Conclusions}

A family has a considerable impact upon the students' academic achievement, including their reading skills. The role of parents is fundamental for enhancing reading literacy.

Parents' education is one of the key factors affecting students' reading literacy and academic achievement.

Parents' education correlates with the frequency of their undertaken reading promotion activities.

The parents' undertaken reading promotion activities at the preschool age have a profound impact upon the students' reading literacy in Grade 4. However, this impact differs across countries, possibly due to other factors that are not included in the study. The impact of Latvian parents' activities upon their children's reading achievement is not high in comparison with other countries; most likely, parents lack the relevant skills.

There is no one particular activity that would resolve the development of children's reading literacy. Parents who undertake their chosen activity are more likely to engage in other activities. Nonetheless, the most direct activities are 
SOCIETY. INTEGRATION. EDUCATION

Proceedings of the International Scientific Conference. Volume III, May $22^{\text {th }}-23^{\text {th }}, 2020.656-666$

reading together and storytelling at the preschool age, which can greatly increase the students’ reading achievement.

\section{References}

Araujo, L., \& Costa, P. (2011). Home Book Reading and Reading Achievement in EU Countries: The Progress in International Reading Literacy Study 2011 (PIRLS). Retrieved from https://doi.org/10.1080/13803611.2015.1111803

Cain, K., Bryant, P., \& Oakhill, J. (2004). Children’s Reading Comprehension Ability: Concurrent Prediction by Working Memory, Verbal Ability, and Component Skills. Journal of Educational Psychology, 96(1), 31-42. Retrieved from https://pdfs.semanticscholar.org/143f/4cde21935e86bc21176e7e16c54e35c02559.pdf

European Union. (2012). EU High Level Group of Experts on Literacy. Retrieved from https://ec.europa.eu/assets/eac/education/policy/school/doc/literacy-report_en.pdf

Gove, A., \& Cvelich, P. (2011). Early Reading: Igniting Education for All. A Report by the Early Grade Learning Community of Practice. Retrieved from https://www.rti.org/ sites/default/files/resources/early-reading-report-revised.pdf

Human Resource Development Centre. (2017). Lasītmācī̌sana viegli un ar prieku. Rokasgrāmata skolotājiem. Retrieved from http://easereading.org/wp-content/uploads/ 2015/12/Handbook_LV.pdf

Latvijas Kultūras akadēmija. (2018). Pētījums par Latvijas iedzīvotāju lasīšanas paradumiem. Pieejams http://www.gramatizdeveji.lv/_files/Petijums_gramatu_lasisanas_paradumi_fe b_2018.pdf

Myrberg, E., \& Rosen, M. (2009). Direct and Indirect Effects of Parents' Education on Reading Achievement among Third Graders in Sweden. British Journal of Educational Psychology, 79, 695-711. Retrieved from https://onlinelibrary.wiley.com/doi/pdf/ 10.1348/000709909X453031

Organisation for Economic Co-operation and Development. (2017). PISA 2015 Technical Report. OECD Publishing: Paris. Retrieved from https:/www.oecd.org/pisa/ sitedocument/PISA-2015-technical-report-final.pdf

Scottish Government. (2010). Literacy Action Plan. An Action Plan to Improve Literacy in Scotland. Retrieved from http://www.gov.scot/Resource/Doc/328493/0106197.pdf

Vanags, E. (2019). Pētījums: regulāra priekšā lasīšana bērnam ietekmē viña karjeras iespējas nākotnē. Pieejams http://www.mammamuntetiem.lv/articles/30836/petijums-regularaprieksa-lasisana-bernam-ietekme-vina-karjeras-iespejas-nakotne/

Wildova, R., \& Kropackova, J. (2015). Early Childhood Pre-reading Literacy Development. Procedia - Social and Behavioral Sciences, 191, 878-883. Retrieved from https://www.researchgate.net/publication/282536477_Early_Childhood_Pre-reading_ Literacy_Development/fulltext/5611d90508ae6b29b49e37ef/282536477_Early_Childh ood_Pre-reading_Literacy_Development.pdf 